\title{
Vocabulary Coursebook for EFL Learners of Higher Education in Indonesia
}

\author{
Yudi Basuki*, Astried Damayanti, Sri Utami dewi \\ English Language Education Studying program, STKIP PGRI Trenggalek, East Java, Indonesia \\ Corresponding author: Yudi Basuki, E-mail: jude.q13@gmail.com
}

\section{ARTICLE INFO}

Article history

Received: September 28, 2018

Accepted: October 28, 2018

Published: October 31, 2018

Volume: 6 Issue: 4

Conflicts of interest: None

Funding: None

\begin{abstract}
Indonesian Ministry of Education decree number 36 (2001) outlines that coursebook (buku ajar) is a handbook for a course written by experts in related fields. It is written to obtain the qualifications and features of textbooks and to finally be published and distributed. In an attempt to implement the decree, the objective of this research was to develop vocabulary coursebook for the higher education students of English education program. In fact, there is no vocabulary book that meets students' needs and qualifications of the coursebook (buku ajar). This research was a Research and Development (R\&D) study with an industry-based development model. The subjects of the research were all active students at English education program of STKIP PGRI Trenggalek in 2017/18 and 2018/19 academic year. Data were collected using questionnaires and observation. The data collected by questionnaires were analyzed quantitatively and the data collected through observation was analyzed qualitatively. Research findings proved that the product was successful to obtain the vocabulary coursebook for the higher education students of English education program since it met the government qualification of coursebook standards and features, accommodated the students' needs and interests, provided recent theories of vocabulary learning, acquired the learning outcome of vocabulary study area as stated in syllabus, and was systematically developed in five steps development. More importantly as the result of the field-test of the product indicated supportive responses from teacher and students teaching-learning vocabulary in English education program.
\end{abstract}

Key words: Coursebook (buku ajar), Vocabulary, Higher Education

\section{INTRODUCTION}

Basuki (2017, p.13) argues that "for many years teaching learning English vocabulary has been done for higher education students learning English in the EFL context as Vocabulary subjects". Meanwhile, Indonesian minister of education decree number 49 the year 2014 verse 8 and 9 outlines that standard content of learning process is the minimum criteria of the depth and coverage level of learning materials and it should be based on the description of the graduation learning outcome of the Indonesian national qualification framework (KKNI). Hence, the English language education program of STKIP-PGRI Trenggalek curriculum which is based on the Indonesian national qualification framework (KKNI) states that the learning outcome of vocabulary area of study is to make students able to analyze, distinguish and use most common English words used in writing and speech as the basis of interpersonal communication which is in line with the daily life norms.

Unfortunately, the content of the vocabulary textbooks existing nowadays is not sufficient enough to fulfill the learning outcome of the vocabulary area of the study mentioned above. Mostly books/textbooks/workbooks of vocabulary today contain the general knowledge of vocabulary.
However, the vocabulary textbooks do not accommodate what needs and interest of the students of English education program of STKIP-PGRI Trenggalek. In accordance with it, Indonesian minister of education decree number 36 (2001) in a nutshell states that coursebook (buku ajar) is a handbook for a course written by experts in related fields. It is written to obtain the qualifications and features of textbooks and to finally be published and distributed. Thus, in an attempt to implement the mentioned decree, accommodate the students' needs and fulfill the learning outcome of the vocabulary area of the study above, the objective of this research was merely to develop vocabulary coursebook for the higher education students of English education program.

In this line, this research is answering the following question "how to develop the Vocabulary coursebook (buku ajar) for higher education students of English language education program in Indonesia?"

\section{LITERATURE REVIEW}

\section{Vocabulary}

Getting to know vocabulary according to some experts that is as a 'dictionary' or a set of words" (Takac, 2008, p.4). 
Similarly, Cambridge Advanced Learner's Dictionary (2008) defines vocabulary as every single of the words that exist in specific language or dialect. Meanwhile, Vygotsky in Thornbury (2008) states that a word is a microcosm of human awareness. Thus, vocabulary is words that exist in every language, dialect or subject as a small part which has the same characteristics as something much larger.

Further, vocabulary is seen as an important component of language. The linguist David Wilkins in Thornbury (2008, p.13) strictly argues that "without grammar very little can be conveyed, without vocabulary nothing can be conveyed". In addition, Allen (1983) states, experienced teacher of English as a second language know very well how important vocabulary is. They know students must learn thousands of words that speakers and writers of English use. Fortunately, the need for vocabulary is one point on which teachers and students agree! Thus, vocabulary is very important; it is as the core of language complexities and as a starting point of those who are learning a new language. We have to believe that learner who wants to improve his or her language she/he will get most improvement if she/he learns more words and expressions than other language components.

However, learning vocabulary does not seem as simple as such way. The vocabulary materials must be selectively chosen whether it is to acquire a specific and/or general target of language learning or others. In addition, Thornbury (2008) argues that vocabulary teaching has not generally been extremely receptive to such issues and the teachers have not completely perceived the tremendous communicative advantage in building up an extensive vocabulary. Despite all considerations of vocabulary materials that the students should learn, Thornbury (2008) headlines two major vocabulary materials to teach; word parts and word chunks, that cover some vocabulary materials such word formation (affixation), word combination (compounding, phrase, conversion), a lexical approach, lexical chunks, word grammar, phrasal verb, idioms, and etc.

\section{Coursebook (buku ajar)}

On the other hand, the term coursebook used in this research carries meaning for the primary book for a term, semester or year (Harmer, 2007). In addition, Ur (1996) defines the term coursebook as a textbook of which the teacher and every learner have a duplicate, and which is in principle to be pursued systematically as the basis for a language course (as cited in Basuki, 2017). Interestingly, Indonesian minister of education decree number 36 year 2001 verse 5 states "Buku ajar adalah buku pegangan untuk suatu matakuliah yang ditulis dan disusun oleh pakar bidang terkait dan memenuhi kaidah buku teks serta diterbitkan secara resmi dan disebar luaskan" It means that buku ajar (coursebook) is a handbook for a course written by experts in related fields. It is written to obtain the qualifications and features of textbooks and to finally be published and distributed. Dealing with material development as an accomplishment of the coursebook mentioned above, Tomlinson (2012, p.143) states that "materials development refers to all the processes made use of by practitioners who produce and/or use materials for language learning; including materials evaluation, their adaptation, design, production, exploitation and research". Tomlinson (2012) also states there are six steps of materials development such as materials evaluation, materials adaptation, production, exploitation and research.

\section{Higher Education}

Higher education/college can simply mean any school for a particular education after the age of 16 or after completing secondary school to prepare individuals to get knowledge/ skill and to prompt a specific degree (Basuki, 2017). Meanwhile, Webster's Encyclopaedic Unabridged Dictionary of the English Language (1989) defines higher education as a school in the U.S. that you go to after secondary school: a school that offers a course prompting a degree, (for example, a four-year certification of an associate's degree).

Further, Siregar as cited in Hidayah (2012) notifies that higher education students are members of society who have some characteristics as follows; first, higher education students have the ability and opportunity to study in higher education or university then they can be categorized as intellectuals. Second, in the future higher education students are expected to be able to be a skillful leader, whether a leader in society or workplace. Third, higher education students are expected to be able to be a dynamic motivator for modernization process. Fourth, higher education students are expected to be able to get a job as a qualified and professional employee.

Meanwhile, to achieve those expectations of higher education students 'characteristics above, they must be well educated in higher education. Especially in Indonesia, the higher education is based on higher education curriculum which is based on the Indonesian national qualification framework (KKNI) cited as Indonesian minister of education decree number 49 (2014). Meanwhile, curriculum is a set of plan and regulation about learning outcome, learning material, process, and assessment which is used as the guide to running the majority of higher education or university. Further, Indonesian minister of education decree number 49 (2014) outlines that the Higher Education National Standard (SNPT) in chapter II (national education standard) covers some aspects of higher education standard such as graduation competence standard, learning content standard, learning process standard, learning assessment standard, teacher and apparatus standard, and utilities standard.

\section{Previous Study}

Basuki (2017) attempted to develop the requisite vocabulary material for college students of English education department. He combined students' needs with the sound of vocabulary theories, the existed curriculum, government regulation and textbook's standard features and writing design into a vocabulary coursebook package. His research resulted from a developed material which was able to accommodate the students' needs and interest in learning vocabulary, provide recent theories of vocabulary learning materials and acquire the learning outcome of vocabulary subject. Similarly, 
the present research is also aimed to develop the vocabulary material for higher education students of English language education program. The distinctions between previous and present research lie on the developed product, subjects and period of the research. The developed product of the present research is buku ajar kosa kata (vocabulary coursebook) which the definition has been stated above. Meanwhile, the subjects and the period of the present research are larger and longer than the previous research. It involves all active students in English language education program in 2017/2018 and 2018/2019 academic year.

\section{METHOD}

\section{Type of the Research}

In this research Gall et al.'s (2003) educational R\&D model was followed. They describe educational R\&D as an industry-based development model whose findings are used to design new products and procedures, which then are systematically field-tested, evaluated, and refined until they meet specified criteria of effectiveness, quality, or similar standards. To develop the vocabulary coursebook for higher education students in this research, the researchers take five steps in Figure 1.

\section{Setting and Subject of the Research}

This research was conducted in STKIP - PGRI Trenggalek. It is located at Supriyadi street number 22 Trenggalek, East Java, Indonesia. Then, the Subjects of the research were hundreds of all active students in English language education program in 2017/2018 and 2018/2019 academic year. Meanwhile, the object of this research is a vocabulary coursebook (buku ajar) which the product specifications are in the form of coursebook (buku ajar). Its features consist of some students' exercise activities, chapter summary, students' washback and feedback pages, instructional analysis, acknowledgment, index, glossary, biography of the writers, guidance page of how to use the book for teachers and students, and communicative, systematic, flexible, and structured writing style based on students' needs and learning outcomes. It is also completed with a direction of use for teachers and students, explanation of each assigned topic, example of vocabulary usage with illustrations and pictures, evaluation in each topic, and students' feedback page in each chapter. It is a rectangular-shaped book with a hardcover. The book is $23 \mathrm{~cm} \times 16.5 \mathrm{~cm}$ in size.

\section{Instrument of the Research}

Meanwhile, in collecting the data of this research, the researchers implement two kinds of instrument: they are questionnaires and observation. Both are designed by the researchers. The researchers intend to use questionnaires instrument three times. First, it is to obtain the data of students' needs. It is used in the process of needs analysis. It uses "Yes" and "No" questions. It consists of some questions to know students' opinions about their needs and interests in learning vocabulary. The second and the third, the researchers use the questionnaires instrument to students and teacher to know whether the product is applicable in the learning process or demanded to be revised after the product has been field-tested. Lastly, the researchers use observation as an instrument in this research to observe the process of field-test of the product of materials development in class to get the data related to the applicability of developed material in the real vocabulary teaching and learning. Meanwhile, to know the validity and reliability of the instruments, the researchers piloted them before they are implemented to all of the respondents. By incorporating Pearson Product Moment correlation at $5 \%$ level of significance $(\alpha)$, the researchers randomly took 50 students and 10 English teachers as respondents to test the validity of 85 items of the questionnaire and observation. As a result, the coefficient of Pearson Product Moment correlation resulted rC (count) 0.254 which

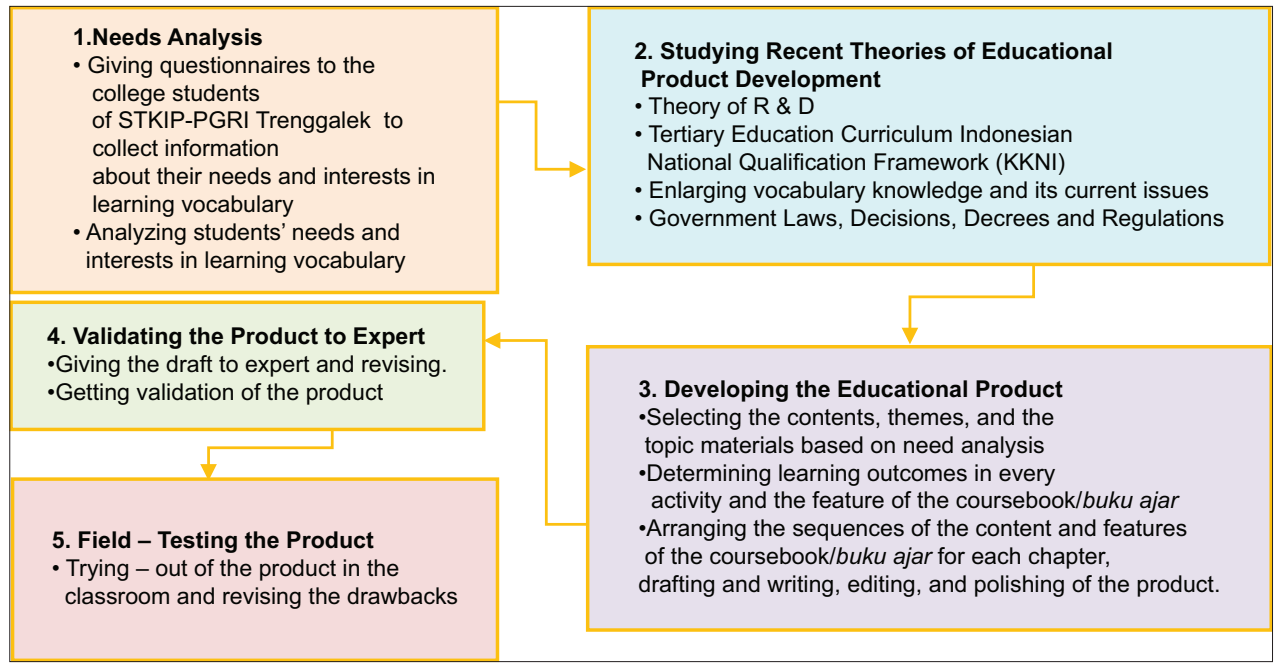

Figure 1. The development steps of vocabulary coursebook (adapted from Latief, 2012) 
was higher that the rT (table). Thus, it can be said that the instruments were valid. Further, the reliability of the instruments was tested by incorporating Alpha Cronbach Formula. It is relevant to the instruments that need scaled or dichotomous answers. The result of reliability test of 85 question items was 0.974 . The questions (instruments), they are said reliable if their Alpha Cronbach's score is higher than 0.7 . Therefore, the research instruments were valid and reliable.

\section{Data analysis}

The data collected in this research are analyzed quantitatively and qualitatively. The data in the form of the questionnaire is analyzed quantitatively by using the Guttman scale. Meanwhile, the collected data from observation is analyzed qualitatively by using descriptive qualitative that the researchers describe the collected data based on the observation checklist sheet.

\section{RESULTS}

\section{Finding on Needs Analysis}

Table 1 presents the results of students' vocabulary learning needs:

Thus, as the need of students on learning vocabulary had been found, then it can be taken as the basis of material development on vocabulary coursebook that is sufficed by theoretical and practical knowledge of vocabulary that is presented systematically following the coursebook (buku ajar) writing standards in a contextualized, meaningful and useful way.

\section{The Vocabulary Coursebook's Characteristics, Contents and Features}

Figure 2 presents the vocabulary coursebook's characteristics, contents and features as the following:

The material development (Buku Ajar vocabulary) as the product of this research presented the themes communicatively and attractively with CMU (contextual, meaningful and useful) teaching-learning principles, that was to boost students' interest, motivation, curiosity and eagerness to read and to finally acquire the learning outcome as mentioned in curriculum and syllabus. Each theme of the book was started from providing instructional analysis, course overview, short course description, learning guidance, course competency, basic and standard competency, indicators of accomplishments and course relevancy to get the depiction of the theme materials. By the end of each theme, the students may have summary, evaluation, washback, feedback, follow up and reference/further reading to accommodating their learning accomplishment, learning issues and strengthening their knowledge.

\section{Product Comparison Before and After Validation by Expert}

Table 2 below presents the book comparison before and after validation by expert:

\section{Findings on Field-Testing the Product}

Table 3 presents the findings on field-testing the product as follows:

As the expert validation and the field-test results indicated supportive responses from the expert, teacher and students, the research development on the vocabulary coursebook (buku ajar) for higher education students of STKIP - PGRI Trenggalek was accomplished. As the final step to meet the qualification of coursebook (Buku Ajar) mentioned above, then, the book was ready to be printed, published and distributed to all people in the educational setting who find the necessities of the book.

\section{Discussion of the Research Findings}

The discussion highlights some viewpoints concerning to the book content, practicality, material development, perfection, approach and orientation and impact. First, concerning to the book content found in this research that was already in line with what expert, Thornbury (2008) proposes two major aspects of vocabulary to teach; word parts and word chunks,

Table 1. Finding on students' questionnaire on vocabulary learning

\begin{tabular}{|c|c|}
\hline \multirow[t]{5}{*}{$\begin{array}{l}\text { Finding on students' questionnaire } \\
\text { on vocabulary material needs }\end{array}$} & $\begin{array}{l}\text { Nearly } 95 \% \text { of students expected to have a good grounding in theoretical and practical } \\
\text { knowledge of vocabulary including collocation, word stalks, comparison, determiners, } \\
\text { punctuation and phrases as a basis of language complexity }\end{array}$ \\
\hline & $\begin{array}{l}\text { More than } 80 \% \text { of students needed sufficient strategies/techniques to study and preserve } \\
\text { vocabularies for further language's skill developments }\end{array}$ \\
\hline & $\begin{array}{l}96 \% \text { of students wanted to have content of the material presented contextually, usefully and } \\
\text { meaningfully }\end{array}$ \\
\hline & $\begin{array}{l}\text { Nearly } 90 \% \text { students agreed to have materials that obtain the learning outcome of the syllabus } \\
\text { which says "the learning outcome of vocabulary area of study is to make students able to } \\
\text { analyze, distinguish and use most common English words used in writing and speech as the basis } \\
\text { of interpersonal communication which is in line with the daily life norms" }\end{array}$ \\
\hline & $\begin{array}{l}\text { Nearly } 90 \% \text { students needed a coursebook which is completed by all required materials, basic } \\
\text { and standard competence, indicators of accomplishments, summary, evaluation, washback, } \\
\text { learning guidance etc., in one packet as the features of Buku Ajar }\end{array}$ \\
\hline
\end{tabular}




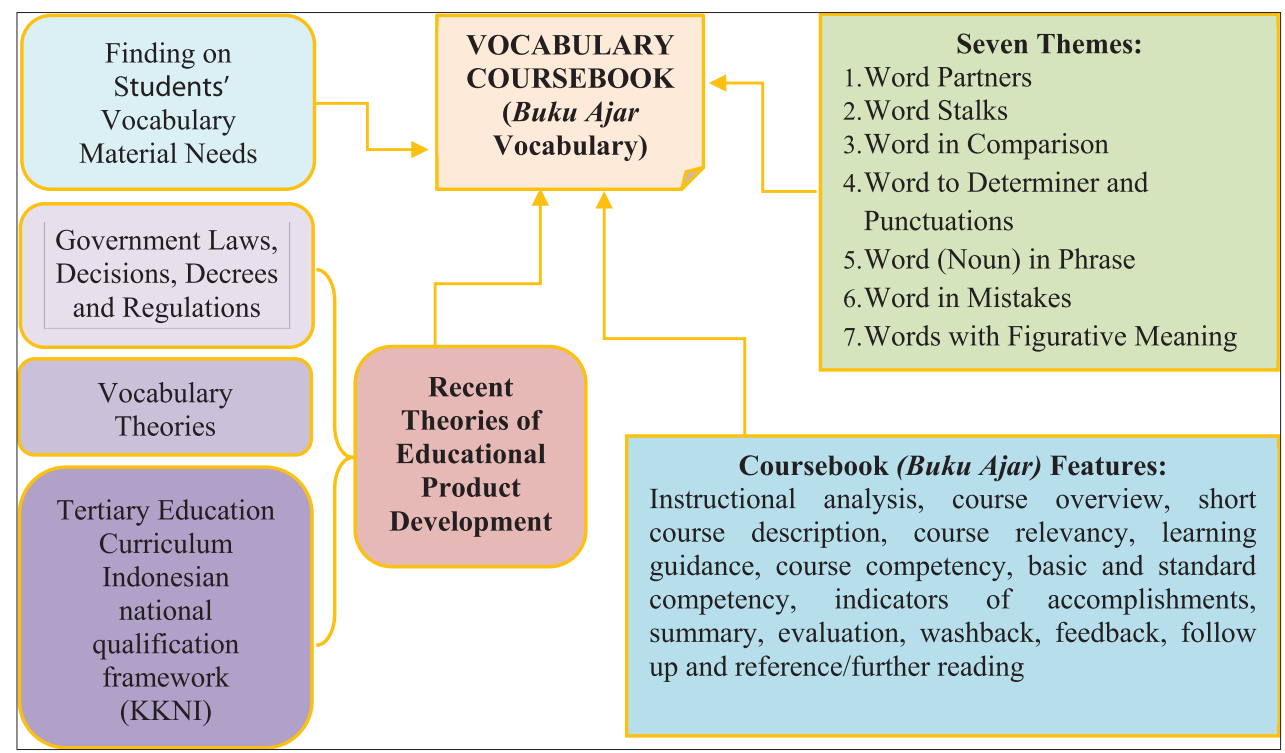

Figure 2. Vocabulary coursebook's (buku ajar vocabulary) characteristics, contents and features (Adapted from Basuki, 2017)

Table 2. The book comparison before and after validation by expert

\begin{tabular}{ll}
\hline Before & After \\
\hline The writing style was not formal and academic enough yet & The formal and academic writing style \\
$\begin{array}{l}\text { The evaluation did not accommodate all level of Indonesian national } \\
\text { qualification framework (KKNI) and/or bloom taxonomy of } \\
\text { acquisition of bachelor degree }\end{array}$ & $\begin{array}{l}\text { The evaluation accommodated all level of Indonesian } \\
\text { national qualification framework (KKNI) and/or bloom } \\
\text { taxonomy of acquisition of bachelor degree }\end{array}$ \\
$\begin{array}{l}\text { The cover of the book and the front page of each theme were not } \\
\text { attractive and noticeable yet }\end{array}$ & $\begin{array}{l}\text { More attractive and noticeable book cover and the front page } \\
\text { of each theme }\end{array}$ \\
A little illustration and/or picture to support the material explanation & $\begin{array}{l}\text { Enough illustration and/or picture to support the material } \\
\text { explanation }\end{array}$ \\
$\begin{array}{l}\text { Spelling, punctuation marks, aligning, font size and line spacing } \\
\text { were not quite appropriate and consistent }\end{array}$ & $\begin{array}{l}\text { Correct spelling and punctuation marks and consistent } \\
\text { aligning, font size and line spacing }\end{array}$ \\
\hline
\end{tabular}

Table 3. Field-testing the product

\begin{tabular}{ll}
\hline Source & Findings \\
\hline $\begin{array}{l}\text { Students' questionnaire after the implementation } \\
\text { of the product }\end{array}$ & $\begin{array}{l}\text { The materials were meaningful for the students to promote their vocabulary } \\
\text { knowledge as the basis of language skills' complexity. The students found the } \\
\text { material was easy enough to understand since it might be presented contextually and } \\
\text { usefully with sufficient illustrations, analogies and pictures. The book simplified the } \\
\text { students' learning sources since it might become the book all they need. Attractive, } \\
\text { handy, practical and applicable materials to boost the students' motivation to read }\end{array}$ \\
$\begin{array}{l}\text { The materials in the book were applicable to teaching vocabulary subject since they } \\
\text { of the product } \\
\text { might be arranged in good approaches and orientations and based on the current } \\
\text { curriculum. The book reduced the students' dependency on the teacher since it } \\
\text { might be communicative enough to speak what the teacher was supposed to speak in } \\
\text { delivering the materials. The teaching and learning processes were satisfying, easier, } \\
\text { effective and efficient since the book might accommodate the learning guidance in } \\
\text { what should the students achieve, do, measure, write on learning issue and follow up } \\
\text { The teacher and students merely looked motivated and enthusiastic to try the } \\
\text { book. They grasped the materials in the book with ease. The teacher and students } \\
\text { merely followed on step by step from the description of the course to feedback } \\
\text { of the course materials with ease. The teaching and learning process by using the } \\
\text { book in the classroom was successfully done by teacher and students which was } \\
\text { just not listening and speaking activities done but living and breathy discussion, } \\
\text { confirmation, quizzes, questions and answers and material enrichment based on } \\
\text { the assigned material being taught in the book }\end{array}$ \\
\hline
\end{tabular}


that cover some vocabulary materials such word formation (affixation), word combination (compounding, phrase, conversion), a lexical approach, lexical chunks, word grammar, phrasal verb, idioms, and so on.

Second, concerning to practicality of the coursebook (buku ajar) found in this research, Indonesian Ministry of Education decree number 36 (2001) stated previously that the buku ajar (coursebook) is ". buku pegangan untuk suatu matakuliah yang ditulis dan disusun oleh pakar bidang terkait dan memenuhi kaidah buku teks serta diterbitkan secara resmi dan disebar luaskan" It means that buku ajar (coursebook) is a handbook for a course written by experts in related fields. It is written to obtain the qualifications and features of textbooks and to finally be published and distributed.

Third, concerning to material development steps proved in this research that took five steps as Latief (2012) stated previously, there are five steps in material development including; identifying the classroom problems (needs analysis), studying recent theories of educational product development, developing the educational products, validating the products to experts, and field testing the products.

Fourth, concerning the view that the book in this research might not be a perfect book, as Grant (1991, p.118) stated: "the perfect textbook does not exist, but the best book available for the teachers and students certainly does". Thus, this coursebook (buku ajar) might be the best book for higher education students of STKIP PGRI Trenggalek studying vocabulary.

Fifth, concerning the approach and orientations of the book found in this research, it could be said that as explained by Grant (1991), the communicative textbooks have the following characteristics: (1) they emphasize the communicative functions of language; (2) they try to reflect the students' needs and interests; (3) they emphasize skills in using the language, not just the forms of language, and they are therefore activity-based; (4) they usually have a good balance among the four language skills; (5) they tend to be very specific in their definition of aims; (6) both content and methods reflect the authentic language of everyday life; (7) they encourage work in groups and pairs; and (8) they emphasize fluency, not just accuracy.

Sixth, concerning the impact of learners' motivation on language (vocabulary) learning; Basuki (2016, p.44) argues motivation to learn language (vocabulary) is "...like to learn such language" interested to do favorable attitudes toward such language. One can be called motivated if one enjoys learning a language, whatever factors influencing one's likes. Finally, one shows favorable attitude and will to exert the goal of learning a language.

\section{CONCLUSIONS}

A conclusion holds true is that the product of developed material in the form of vocabulary coursebook (buku ajar) which is systematically developed in five steps through a developmental research is successful to obtain the vocabulary learning material for higher education students of English education program.

First, the book meets the government regulation of coursebook (buku ajar) standard writing and features. It is the handbook for a course that is written and compiled by experts in related fields and obtains the rules of textbooks in order to be officially published and distributed. It provides and presents the materials communicatively and attractively with CMU (contextual, meaningful and useful) and SCL teaching-learning principles. It features consist of the instructional analysis, course overview, short course description, learning guidance, course competency, basic and standard competency, indicators of accomplishments, course relevancy, summary, evaluation, students' feedback (washback) and reference/further reading.

Second, the book accommodates the students' needs and interest which were in line with the recent theories of vocabulary learning materials. Nearly $95 \%$ of students expected to have a good grounding in theoretical and practical knowledge of vocabulary learning materials including collocation, word stalks, comparison, determiners, punctuation and phrases as a basis of language complexity.

Third, the book acquires the learning outcome of the vocabulary study area as stated in the syllabus which says that the learning outcome of the vocabulary area of the study is to make students able to analyze, distinguish and use most common English words used in writing and speech as the basis of interpersonal communication which is in line with the daily life norms.

Fourth and more importantly, as the result of expert validation and the product field-testing, the coursebook gets the supportive responses from the expert, teacher and students. They were satisfied and motivated with it. The book once was proved practical enough to be implemented in a real vocabulary classroom and able to boost students' interest, motivation, curiosity and eagerness to read and to finally acquire the learning outcome as mentioned in the curriculum and syllabus.

In conclusion, the developed buku ajar kosa kata (vocabulary coursebook) may be beneficial to become a reference book for the teachers and the higher education students teaching-learning vocabulary of the English education program since the book covers a certain science discipline (vocabulary); fulfills the regulations of science writing; be officially published and distributed; be written to achieve the learning outcome as demanded from policies; be sustainable and transfer knowledge; achieve the qualified and targeted learning; be a source of readings and exercises; enhance motivation and interest to read and understand knowledge; and decrease the students' dependency on the teachers.

\section{ACKNOWLEDGEMENT}

The research is financed by the Ministry of Research, Technology and Higher Education of the Indonesian Republic.

\section{REFERENCES}

Allen, V. F. (1983). Techniques in Teaching Vocabulary. New York: Oxford University Press.

Basuki, Y. (2016). The Use of Peer-Assessment of Reading Aloud to Improve the English Department Students' 
motivation on Pronunciation Class of STKIP PGRI Trenggalek. Jurnal Pendidikan Dewantara. 2(1). Retrieved from: http://journal.stkippgritrenggalek.ac.id/ index.php/kid/article/view/52

Basuki, Yudi. (2016). The Use of Peer-Assessment of Reading Aloud to Improve the English Department Students' motivation on Pronunciation Class of STKIP PGRI Trenggalek. Jurnal Pendidikan Dewantara. 3(1). Retrieved from http://journal.stkippgritrenggalek.ac.id/index.php/kid/article/view/81/43

Gall, M. D., Gall, J. P. \& Borg, W. R. (2003). Educational Research: An Introduction. New York: Pearson Education Inc.

Grant, N. (1991). Making the Most of Your Textbook. New York: Longman.

Harmer, J. (2007). How to Teach English? Longman: Pearson Education.
Hidayah, A. (2012). Gambaran Motivasi Belajar Mahasiswa Keperawatan Program S1 Reguler Yang Kuliah Sambil Bekerja. (Unpublished Thesis). Fakultas Ilmu Keperawatan. Universitas Indonesia.

Latief, M. A. (2012). Research Methods on Language Learning: An Introduction. Malang: UM Press.

Takac, P. P. (2008). Vocabulary Learning Strategies and Foreign Language Acquisition. Great Britain: Cromwell Press Ltd.

Thornbury, S. (2008). How to Teach Vocabulary. Malaysia: Pearson Education Limited.

Tomlinson, B. (2012). Materials Development for Language Teaching and Learning, 45(2), 143-179, Cambridge University Press. Retrieved from http://journals.cambridge.org.

Webster's Encyclopedic Unabridged Dictionary of the English Language. (1989). New York: Avenel. 